\title{
Expression of hypoxia-inducible factor $3 \alpha$ in hepatocellular carcinoma and its association with other hypoxia-inducible factors
}

\author{
PING LIU $^{1^{*}}$, XIEFAN FANG ${ }^{2 *}$, YANG SONG $^{3}$, JIAN-XIN JIANG $^{4}$, QIAN-JIN HE ${ }^{5}$ and XIANG-JIE LIU ${ }^{6}$ \\ ${ }^{1}$ Department of Surgery, Liyuan Hospital, Tongji Medical College, Huazhong University of Science and Technology, \\ Wuhan, Hubei 430077, P.R. China; ${ }^{2}$ Department of Pediatrics, College of Medicine, University of Florida, \\ Gainesville, FL 32610; ${ }^{3}$ Department of Pharmacy, Mercy Medical Center-Clinton, Clinton, IA 52732, USA; \\ ${ }^{4}$ Department of Hepatobiliary Surgery, Affiliated Hospital of Guiyang Medical College, Guiyang, Guizhou 550001; \\ ${ }^{5}$ Department of General Surgery, The Center Hospital of Huanggang, Huanggang, Hubei 438000; \\ ${ }^{6}$ Department of Rehabilitation, Liyuan Hospital, Tongji Medical College, \\ Huazhong University of Science and Technology, Wuhan, Hubei 430077, P.R. China
}

Received January 24, 2015; Accepted March 1, 2016

DOI: 10.3892/etm.2016.3193

\begin{abstract}
The functional role of hypoxia-inducible factor (HIF) $-3 \alpha$ in the development of hepatocellular carcinoma (HCC) is not yet fully understood. The aim of the present study was to elucidate the association between HIF-3 $\alpha$ expression and the clinicopathological features as well as prognosis of HCC patients. In addition, we investigated the association between HIF-3 $\alpha$ expression and the expression of HIF- $1 \alpha$ and HIF- $2 \alpha$ in tumor tissues. The protein levels of HIF-3 $\alpha$ were determined using immunohistochemical analysis of paraffin sections of 126 paired HCC and peritumoral tissues. $\mathrm{PLC} / \mathrm{PRF} / 5$ cells, a human HCC cell line, were transfected with HIF- $1 \alpha$ and HIF-2 $\alpha$ vectors and HIF-3 $\alpha$ mRNA and protein expression was detected using quantitative polymerase chain reaction and western blot analysis, respectively. The expression of HIF-3 $\alpha$ was upregulated in $46.0 \%(58 / 126)$ and downregulated in $42.9 \%(54 / 126)$ of tumor tissues, respectively, when compared to peritumoral tissues. HIF-3 $\alpha$ protein expression was not associated with peripheral blood vessel invasion, overall survival, or disease-free survival in HCC patients $(\mathrm{P}>0.05)$. In HCC tissues, the levels of HIF-3 $\alpha$
\end{abstract}

Correspondence to: Professor Jian-Xin Jiang, Department of Hepatobiliary Surgery, Affiliated Hospital of Guiyang Medical College, 28 Guiyi Road, Guiyang, Guizhou 550001, P.R. China E-mail: jjx731003@163.com

Professor Xiang-Jie Liu, Department of Rehabilitation, Liyuan Hospital, Tongji Medical College, Huazhong University of Science and Technology, 39 Yanhu Road, Wuhan, Hubei 430077, P.R. China E-mail: liuxiangjie1968@126.com

*Contributed equally

Key words: hepatocellular carcinoma, hypoxia-inducible factor-3 $\alpha$, hypoxia-inducible factor- $1 \alpha$, hypoxia-inducible factor- $2 \alpha$, prognosis protein were positively correlated with HIF-2 $\alpha$, but not with HIF-1 $\alpha$ expression in HCC tissues. HIF-3 $\alpha$ was upregulated in PLC/PRF/5 and Hep3B cells overexpressed with HIF-1 $\alpha$ or HIF-2 $\alpha$. The hypoxic microenvironment of liver cancer did not lead to elevated HIF-3 $\alpha$ protein expression, indicating that HIF-3 $\alpha$ is regulated differently from HIF-1 $\alpha$ in vivo. The correlation between HIF- $3 \alpha$ and HIF- $2 \alpha$ expression at the cellular and tissue levels indicated that HIF- $3 \alpha$ may be a target gene of HIF-2 $\alpha$. The hypoxic microenvironment did not lead to elevation of HIF-3 $\alpha$ protein expression in liver cancer; thus, HIF- $3 \alpha$ may be a target gene of HIF- $2 \alpha$.

\section{Introduction}

Tumor hypoxia was first described in the 1950s, and there is currently increasing evidence to indicate that it is a common feature in numerous types of cancer, including hepatocellular carcinoma (HCC) $(1,2)$. Although $\mathrm{HCC}$ is among the most hypervascular tumor types, it contains hypoxic regions due to rapid cell proliferation and aberrant formation of blood vessels (3). The effects of hypoxia on cells are predominantly mediated by hypoxia-inducible factors (HIF), which consist of an oxygen-regulated subunit (HIF-1 $\alpha, \mathrm{HIF}-2 \alpha$ or HIF-3 $\alpha$ ) and a constitutively expressed HIF-1 $\beta$ subunit (4).

Under normal oxygen pressure and in the presence of $\mathrm{Fe}^{2+}$ and acetone dicarboxylic acid, prolyl hydroxylase domain (PHD) catalyzes the hydroxylation of key amino acid residues in the HIF- $\alpha$ oxygen-dependent degradation domain (5). Hydroxylated HIF- $\alpha$ binds to the Von Hippel-Lindau tumor suppressor and is rapidly degraded via a ubiquitin-proteasome pathway (6). Under hypoxic conditions, HIFs are not modified by PHDs, but dimerize with the aryl-hydrocarbon receptor nuclear translator $(\mathrm{ARNT}) / \mathrm{HIF}-1 \beta$ via interactions with helix-loop-helix and Per/Arnt/Sim domains (5). The HIF heterodimers are translocated to the nucleus, and co-activators such as $\mathrm{CBP} / \mathrm{p} 300$ are recruited (5). The HIF heterodimers recognize and bind hypoxia response elements (HREs) that contain a consensus sequence (G/A) CGTG within 
the promoter regions of target genes to drive adaptive gene transcription $(7,8)$. It has been reported that HIF-1 and HIF-2 regulate the expression of hundreds of genes that are involved in numerous processes associated with cancer biology, including cell survival, tumor angiogenesis, metastasis and resistance to radiation and chemotherapy $(8,9)$.

HIF-3 $\alpha$ is a member of the HIF family and was initially discovered by Gu et al (10) in 1998. HIF-3 $\alpha$ has relatively low sequence identities with HIF-1 $\alpha$ and HIF-2 $\alpha$ (10). HIF- $1 \alpha$ and HIF-2 $\alpha$ have two transactivation domains (TADs) (11), while HIF-3a has only one TAD (12). HIF-3 $\alpha$ has a unique leucine zipper domain and an LXXLL ( $\mathrm{L}$ is Leucine and $\mathrm{X}$ is any amino acid) motif (10). These unique structural features are evolutionarily conserved. Compared with HIF-1 $\alpha$ and HIF-2 $\alpha$, which have been studied extensively (5), little is known about the regulation and function of HIF-3 $\alpha$. Recent studies have indicated that hypoxia induces HIF-3 $\alpha$ expression, and that HIF-3 $\alpha$ may be a target gene of HIF-1 and HIF-2 (13-15). HIF-3 may suppress the expression of genes that are typically inducible by HIF-1 $\alpha$ and HIF- $2 \alpha$ in tumor cells, and therefore, it may be a negative regulator of gene expression in response to hypoxia $(12,14)$.

The expression pattern of HIF-3 $\alpha$ in HCC tissues is currently unknown, and only a few studies have investigated the association between HIF-3 $\alpha$ expression and the expression of HIF-1 $\alpha$ and HIF-2 $\alpha$ (13-15); however, the results are inconsistent or even conflicting. To determine the role of HIF-3 $\alpha$ in hepatocarcinogenesis, immunostaining was used herein to compare HIF-3 $\alpha$ expression in HCC and paired peritumoral tissues obtained from 126 clinical samples. Furthermore, the association between the expression of HIF- $3 \alpha$ and HIF-1 $\alpha / \mathrm{HIF}-2 \alpha$ was assessed in HCC clinical tissues and the human cell lines PLC/PRF/5 and Hep3B.

\section{Materials and methods}

Patients and specimens. Tissue samples from a total of 126 patients with $\mathrm{HCC}$ that underwent a surgical liver resection were obtained between October 2005 and June 2009. Tissue samples for 76 patients were obtained from the Department of Hepatobiliary Surgery of the Affiliated Hospital of Guiyang Medical College (Guiyang, China) and the remaining samples were sourced from 50 patients at the Department of General Surgery of Center Hospital of Huanggang (Huanggang, China). Informed consent was obtained from all patients. The research protocol was approved by the Human Ethics Committees of the Guiyang Medical College and the Center Hospital of Huanggang. All tissue specimens were obtained from the patients prior to any medical treatments. Peritumoral tissues were obtained from at least $2 \mathrm{~cm}$ away from the primary tumor site. All patients tested positively for the hepatitis B antigen $\mathrm{HBs} A g$ and negatively for hepatitis $\mathrm{C}$ virus and human immunodeficiency virus. The cohort had 110 males and 16 females, with an average age of 48.8 years and an age range of 19-66 years. The maximum diameter of HCC tissue was $<5.0 \mathrm{~cm}$ in 60 patients and was $\geq 5.0 \mathrm{~cm}$ in 66 patients. Data from follow-up examinations following liver resection were collected for all patients. The clinical pathological features of the 126 HCC patients are listed in Table I.
Cell culture and transfection. The human HCC cell lines PLC/PRF/5 and Hep3B were purchased from the Institute of Biochemistry \& Cell Biology of the Shanghai Institutes for Biological Sciences (Chinese Academy of Sciences, Shanghai, China). HIF- $1 \alpha$ and HIF-2 $\alpha$ expression plasmids and the control plasmid pcDNA3.1 were purchased from Shanghai Gene Chem Co., Ltd. (Shanghai, China). Cells were grown in six-well plates with Dulbecco's modified Eagle's medium (DMEM; GE Healthcare Life Sciences, Logan, UT, USA) containing 10\% fetal bovine serum (FBS), 2 mmol/l L-glutamine, 50 units $/ \mathrm{ml}$ penicillin and $50 \mathrm{~g} / \mathrm{ml}$ streptomycin (all GE Healthcare Life Sciences) at $37^{\circ} \mathrm{C}$ and in $5 \% \mathrm{CO}_{2}$. PLC/PRF/5 and Hep3B cells at $70-80 \%$ confluence were transfected with $1.2 \mu \mathrm{g}$ plasmids using Lipofectamine ${ }^{\circledR} 2000$ (Thermo Fisher Scientific, Inc., Waltham, MA, USA), following the manufacturer's protocol. Transfected cells were incubated at $37^{\circ} \mathrm{C}$ for $6 \mathrm{~h}$, and were then cultured for a further $16 \mathrm{~h}$ with fresh DMEM medium containing 10\% FBS. The mRNA and protein expression levels of the target genes in the transfected cells were analyzed using quantitative reverse transcription polymerase chain reaction (RT-qPCR) and western blot analysis, respectively.

$R T-q P C R$. Total RNA was isolated from the PLC/PRF/5 and Hep3B cells using TRIzol reagent (Thermo Fisher Scientific, Inc.), as previously described $(16,17)$. To avoid genomic DNA contamination, RNA samples were treated with RNase-free DNase I ( (Takara Bio, Inc., Shiga, Japan) for $20 \mathrm{~min}$ at $37^{\circ} \mathrm{C}$. The quantity and quality of total RNA were determined using a NanoDrop 2000 spectrophotometer (Thermo Fisher Scientific, Inc.). cDNA synthesis was performed at $42^{\circ} \mathrm{C}$ for $60 \mathrm{~min}$ in a total volume of $25 \mu \mathrm{l}$ containing $2 \mu \mathrm{g}$ RNA, $1.6 \mu \mathrm{M}$ oligo(dT)18, $0.6 \mu \mathrm{M}$ dNTPs, $200 \mathrm{U}$ M-MLV reverse transcriptase, and 10X Reaction buffer (all Promega Corporation, Madison, WI, USA). All researchers received biosafety training and were screened and vaccinated against hepatitis B virus. qPCR analysis was performed as described previously $(16,18)$, using a reaction mixture consisting of $10 \mu \mathrm{l}$ 2X SYBR Green mix (Invitrogen; Thermo Fisher Scientific, Inc.), $2 \mu \mathrm{l}$ cDNA template, $0.6 \mu \mathrm{l}$ each of forward and reverse primers $(10 \mu \mathrm{M})$ and double distilled $\mathrm{H}_{2} \mathrm{O}$, to a final volume of $20 \mu \mathrm{l}$. qPCR was performed on a ABI 7500 Real-Time PCR system (Applied Biosystems; Thermo Fisher Scientific, Inc.) with the following cycling program: Denaturation at $94^{\circ} \mathrm{C}$ for $1 \mathrm{~min}$, followed by 40 cycles at $94^{\circ} \mathrm{C}$ for $1 \mathrm{~min}, 55^{\circ} \mathrm{C}$ for $1 \mathrm{~min}$ and $72^{\circ} \mathrm{C}$ for $1 \mathrm{~min}$. The primer sequences were as follows: HIF- $1 \alpha$ forward, 5'-ACTTCTGGATGCTGGTGATTTG-3' and reverse, 5'-GCTTCGCTGTGTGTTTTGTTCT-3'; HIF-2 $\alpha$ forward, 5'-TCATGCGACTGGCAATCAGC-3' and reverse, 5'-GTCACCACGGCAATGAAACC-3'; HIF-3 $\alpha$ forward, 5'-CCTGGACATGAAGTTCACCTACTG-3' and reverse, 5'-GGAAGCGATACTGCCCTGTTA-3'; and $\beta$-actin forward, 5'-AGTTGCGTTACACCCTTTCTTGAC-3' and reverse, 5'-GCTCGCTCCAACCGACTGC-3'. The number of replications was three for each sample. Reactions without template cDNA were used as negative control. The cycle quantification $(\mathrm{Cq})$ values were determined and the data were analyzed using the $2^{-\Delta \Delta \mathrm{Cq}}$ method (19), following normalization to of $\beta$-actin.

Immunohistochemical (IHC) analysis and scoring of protein expression. IHC analysis of the tissue samples was performed 
Table I. Correlations between HIF-3 $\alpha$ protein expression in surgical specimens of HCC and clinicopathological characteristics.

\begin{tabular}{|c|c|c|c|}
\hline \multirow[b]{2}{*}{ Parameter } & \multicolumn{2}{|c|}{ HIF-3 $\alpha$} & \multirow[b]{2}{*}{ P-value } \\
\hline & Low & High & \\
\hline Age (years) & & & 0.200 \\
\hline$<50$ & 13 & 21 & \\
\hline$\geq 50$ & 47 & 45 & \\
\hline Gender & & & 0.202 \\
\hline Male & 50 & 60 & \\
\hline Female & 10 & 6 & \\
\hline Cirrhosis & & & 0.595 \\
\hline Absent & 40 & 41 & \\
\hline Present & 20 & 25 & \\
\hline Tumor size $(\mathrm{cm})$ & & & 0.114 \\
\hline$<5$ & 33 & 27 & \\
\hline$\geq 5$ & 27 & 39 & \\
\hline $\operatorname{AFP}(\mu \mathrm{g} / \mathrm{l})$ & & & 0.377 \\
\hline$<400$ & 32 & 30 & \\
\hline$\geq 400$ & 28 & 36 & \\
\hline Histological grade & & & 0.676 \\
\hline Well & 9 & 8 & \\
\hline Moderate & 43 & 46 & \\
\hline Poor & 8 & 12 & \\
\hline Capsular infiltration & & & 0.526 \\
\hline Absent & 44 & 45 & \\
\hline Present & 16 & 21 & \\
\hline Vascular invasion & & & 0.098 \\
\hline Absent & 42 & 59 & \\
\hline Present & 15 & 10 & \\
\hline
\end{tabular}

Data were analyzed using the two-tailed Mann-Whitney U-test. HIF-3 $\alpha$, hypoxia-inducible factor $3 \alpha$; HCC, hepatocellular carcinoma; AFP, $\alpha$-fetoprotein.

as described previously (18). Briefly, the tissue samples were fixed using 10\% formaldehyde, embedded in paraffin (both Boster Biological Technology, Ltd., Wuhan, China) and rehydrated using ethanol, after which endogenous peroxidase activity was blocked using $3 \% \mathrm{H}_{2} \mathrm{O}_{2}$ in methanol solution (Boster Biological Technology, Ltd.). Subsequently, the tissue samples were cut into $5 \mu \mathrm{m}$ sections using a microtome (Leica RM2155; Leica Microsystems GmbH, Wetzlar, Germany). The sections were then immersed in citrate buffer ( $\mathrm{pH}$ 6.0; Boster Biological Technology, Ltd.) and heated in a microwave oven for $15 \mathrm{~min}$ in order to unmask the antigens, after which the sections were incubated with mouse anti-HIF-3 $\alpha$ (1:250; cat. no. NBP2-45735; Novus Biologicals LLC, Littleton, CO, USA) at $37^{\circ} \mathrm{C}$ for $1 \mathrm{~h}$ and then overnight at $48^{\circ} \mathrm{C}$. After washing three times with phosphate-buffered saline, the sections were incubated with biotin-conjugated goat anti-mouse immunoglobulin $\mathrm{G}(\mathrm{IgG})$ secondary antibody (1:200; cat. no. sc-2075; Santa Cruz Biotechnology, Inc., Dallas, Texas, USA), followed by incubation with horseradish peroxidase (HRP)-conjugated
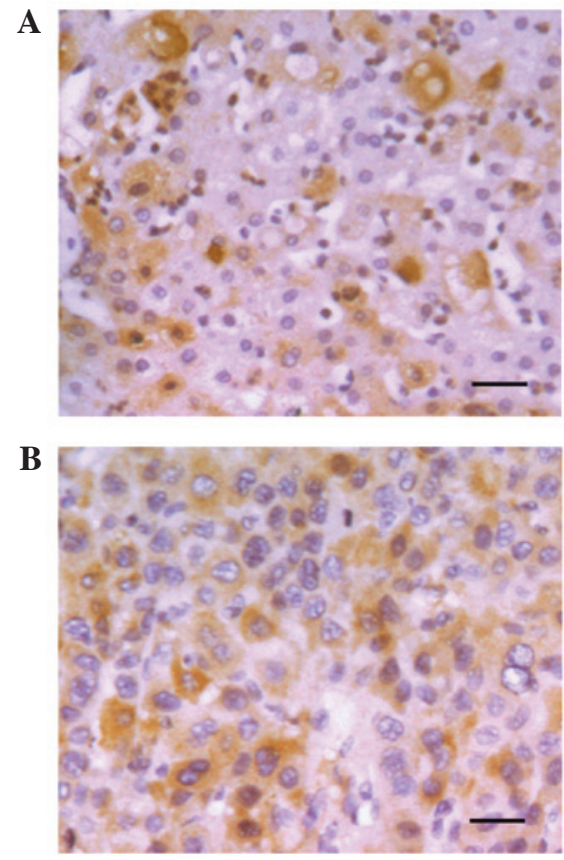

Figure 1. Expression of hypoxia-inducible factor (HIF)-3 $\alpha$ in hepatocellular carcinoma (HCC) tissues was detected by immunohistochemical staining. Representative images of HIF-3 $\alpha$ staining in (A) peritumor and (B) paired HCC tissues are shown (scale bar=10 $\mu \mathrm{m}$ ).

streptavidin (Boster Biological Technology, Ltd.) for $20 \mathrm{~min}$. Detection of immunoreactivity was performed using 3,3'-diaminobenzidine (Boster Biological Technology, Ltd.) under a FV300 fluorescent microscope (Olympus Corporation, Tokyo, Japan).

The protein expression level of HIF-3 $\alpha$ was assessed using the following classification system based on the number of cells with cytoplasmic and nuclear staining: I) No staining; II) nuclear staining in $<10 \%$ of cells and/or with weak cytoplasmic staining; III) nuclear staining in $10-50 \%$ of cells and/or with distinct cytoplasmic staining; and IV) nuclear staining in $>50 \%$ of cells and/or with strong cytoplasmic staining (20-23). The staining scores I and II were considered to be low expression, while the scores III and IV were considered as high expression (20-23). The protein level of HIF-1 $\alpha$ and HIF-2 $\alpha$ in HCC and paired peritumoral tissues has been described in our previous study (18).

Protein preparation and western blot analysis. Cells were lysed in lysis buffer $(50 \mathrm{mM}$ Tris, $\mathrm{pH}$ 7.2, $1 \%$ Triton X-100, $0.5 \%$ sodium deoxycholate, $0.1 \% \mathrm{SDS}, 500 \mathrm{mM} \mathrm{NaCl}, 10 \mathrm{mM}$ $\mathrm{MgCl}_{2}, 10 \mu \mathrm{g} / \mathrm{ml}$ leupeptin, $10 \mu \mathrm{g} / \mathrm{ml}$ aprotinin, $10 \mathrm{ml} / \mathrm{l}$ NP-40, $0.2 \mathrm{~g} / 1 \mathrm{NaN}_{3}$ and $1 \mathrm{mM}$ PMSF; Bio-Rad Laboratories, Inc., Hercules, CA, USA) and the protein concentration was quantified using a Bradford Protein Assay (Bio-Rad Laboratories, Inc.). A total of 30-50 $\mu \mathrm{g}$ protein from each sample was separated using 10\% SDS-PAGE, transferred to polyvinylidene fluoride membranes, and blocked with 5\% nonfat milk in Tris-buffered saline and Tween 20 (Boster Biological Technology, Ltd.) for $2 \mathrm{~h}$ (24). The membranes were then incubated with mouse anti-HIF-3 $\alpha$ (1:250; cat. no. NBP2-45735; Novus Biologicals LLC), HIF-1 $\alpha$ (1:1,000; cat. no. sc-53546; Santa Cruz Biotechnology, Inc.), HIF-2 $\alpha$ 
A

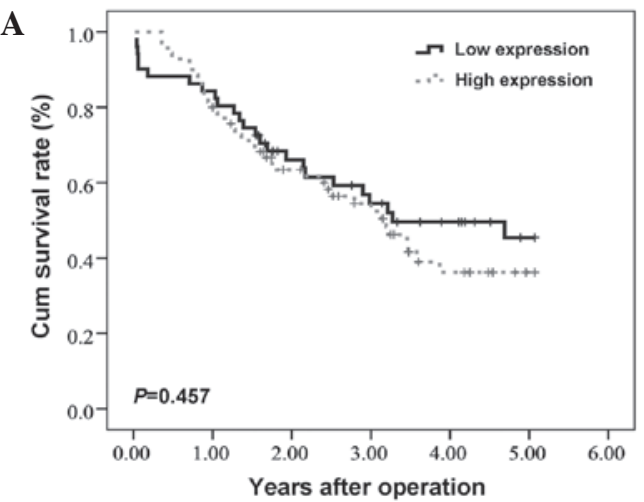

B

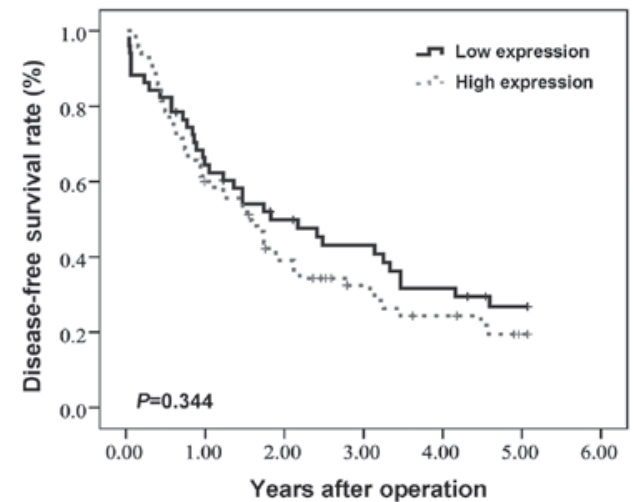

Figure 2. Association between hypoxia-inducible factor (HIF)-3 $\alpha$ expression and the prognosis of patients with hepatocellular carcinoma (HCC). Kaplan-Meier analysis of OS and DFS in 126 HCC patients was performed based on expression of HIF-3 $\alpha$. No significant differences were detected in (A) overall survival or (B) disease-free survival between HCC patients with high and low expression of HIF-3 $\alpha(\mathrm{P}>0.05)$.

A

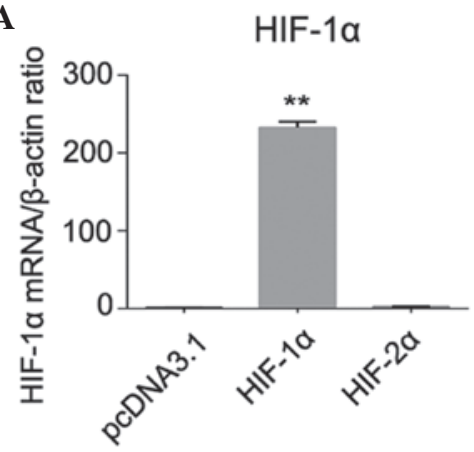

HIF-3a

C

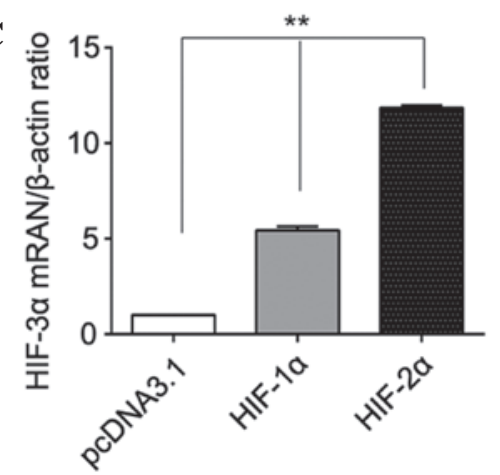

B

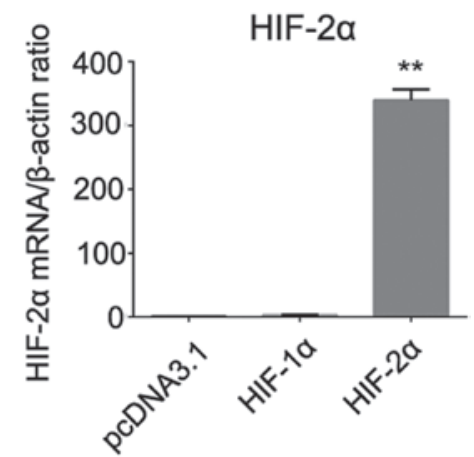

D

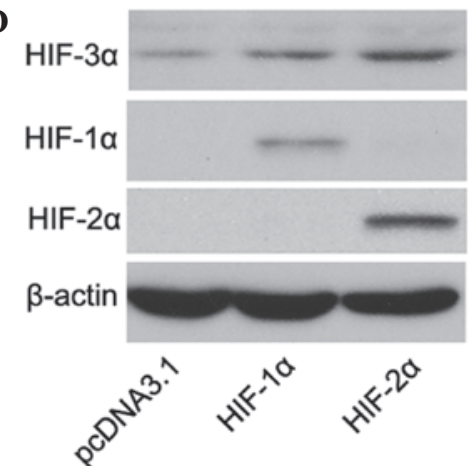

Figure 3. mRNA expression levels of (A) HIF-1 $\alpha$, (B) HIF-2 $\alpha$ and (C) HIF-3 $\alpha$ were detected using quantitative polymerase chain reaction after transfection with various HIF- $\alpha$ plasmids in PLC/PRF/5 cells. pcDNA3.1 was used as a control vector. mRNA expression was normalized against $\beta$-actin and is presented as the relative mRNA expression verses control. Results are an average of three independent experiments. Data were analyzed using a two-tailed Student's t-test and are presented as the mean \pm standard deviation. ${ }^{* *} \mathrm{P}<0.01$ vs. control. (D) Western blot analysis of HIF-1 $\alpha, \mathrm{HIF}-2 \alpha$ and HIF-3 $\alpha$ expression in PLC/PRF/5 cells transfected with pcDNA3.1, HIF-1 $\alpha$ or HIF- $\alpha$ vector. $\beta$-actin was used as a loading control. HIF, hypoxia-inducible factor.

(1:250; cat. no. sc-13596; Santa Cruz Biotechnology, Inc.) and $\beta$-actin (1:3,000; cat. no. sc-47778; Santa Cruz Biotechnology, Inc.) monoclonal antibodies for $1 \mathrm{~h}$ at $37^{\circ} \mathrm{C}$ and at $4^{\circ} \mathrm{C}$ overnight. The membranes were washed and then incubated with HRP-conjugated goat anti-mouse IgG monoclonal antibody (1:2,000, cat. no. sc-2005; Santa Cruz Biotechnology, Inc.) for $1 \mathrm{~h}$ at room temperature. The bands were visualized using an enhanced chemiluminescence detection system (SuperSignal West Pico Chemiluminescent Substrate; cat. no. 34080; Thermo Fisher Scientific, Inc.) and band intensities were calculated using ImageJ software, version 1.41 (https://imagej. nih.gov/ij/).

Statistical analysis. Statistical analysis was performed using SPSS software, version 16.0 (SPSS, Inc., Chicago, IL, USA). Continuous variables were expressed as the mean \pm standard deviation and analyzed using a two-tailed Student's t-test. The correlation analyses between HCC clinicopathological parameters and HIF-3 $\alpha$ expression were conducted using a two-tailed Mann-Whitney U-test. Survival curves were 
A
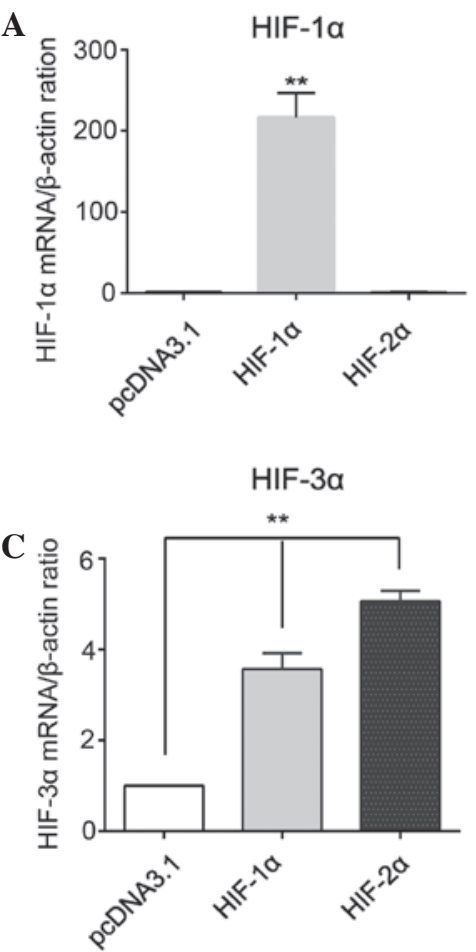

B

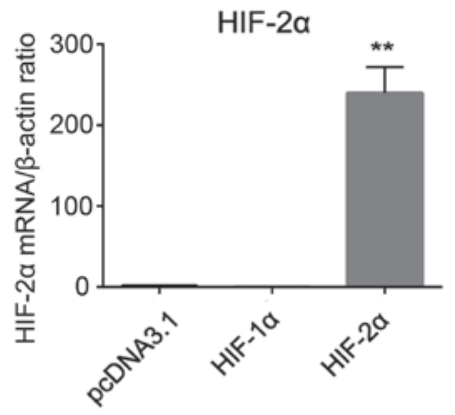

D

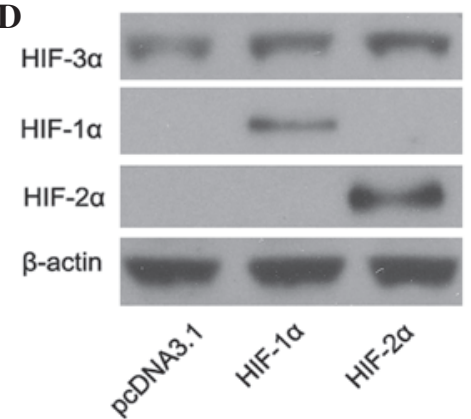

Figure 4. mRNA expression levels of (A) HIF-1 $\alpha$, (B) HIF-2 $\alpha$ and (C) HIF-3 $\alpha$ were detected using quantitative polymerase chain reaction after transfection with various HIF- $\alpha$ plasmids in Hep3B cells. pcDNA3.1 was used as a control vector. mRNA expression was normalized against $\beta$-actin and is presented as the relative mRNA expression verses control. Results were an average of three independent experiments. Data were analyzed using a two-tailed Student's t-test and are presented as the mean \pm standard deviation. ${ }^{* *} \mathrm{P}<0.01$ vs. control. (D) Western blot analysis of HIF-1 $\alpha$, HIF-2 $\alpha$ and HIF-3 $\alpha$ expression in Hep3B cells transfected with pcDNA3.1, HIF-1 $\alpha$ or HIF-2 $\alpha$ vector. $\beta$-actin was used as a loading control. HIF, hypoxia-inducible factor.

computed by Kaplan-Meier analysis. Linear associations were evaluated using Spearman's Rank or Pearson's correlation coefficients. Prognostic significance was analyzed using a log-rank test. $\mathrm{P}<0.05$ was considered to indicate a statistically significant difference.

\section{Results}

Expression of HIF-3 $\alpha$ in HCC tissues. The protein level of HIF-3 $\alpha$ was measured using IHC analysis on paraffin-embedded sections of 126 human HCC samples and paired peritumor tissues. Positive staining of HIF-3 $\alpha$ was located in cytoplasm and/or nuclei of HCC tissues, with representative staining shown in Fig. 1A. High expression of HIF-3 $\alpha$ was found in 66/126 tumor tissues (52.3\%) and $63 / 126$ peritumoral tissues $(50.0 \%)$. The expression of HIF-3 $\alpha$ was upregulated in $46.0 \%(58 / 126)$ and downregulated in $42.9 \%(54 / 126)$ of tumor tissues, when compared with the peritumoral tissues. No obvious difference in HIF-3 $\alpha$ expression was identified between the remaining $11.1 \%$ (14/126) of tumor and peritumoral tissues. Our previous study showed that HIF-1 $\alpha$ was higher in HCC tissues compared with peritumoral tissues (18). Therefore, as opposed to HIF-1 $\alpha$, the hypoxic microenvironment in liver cancer did not increase HIF-3 $\alpha$ protein expression.

Next, we analyzed the association between HIF-3 $\alpha$ expression and pathological features of HCC. As shown in Table I, no significant correlation was found between HIF-3 $\alpha$ expression and the clinicopathological features of HCC, including age, gender, presence of liver cirrhosis, tumor size, serum $\alpha$-fetoprotein level, tumor differentiation grade, capsular infiltration and portal vein invasion.

Disease-free survival (DFS) and overall survival (OS) of $H C C$ patients. The correlation between HIF-3 $\alpha$ expression and long-term patient survival following hepatectomy was analyzed. No significant correlation was found between HIF-3 $\alpha$ expression levels in HCC tissues and the OS or DFS times of HCC patients. The mean OS periods for patients with high and low HIF-3 $\alpha$ expression levels in their tumor tissues were $36.5 \pm 2.7$ and $39.0 \pm 3.3$ months $(P=0.457)$, respectively. The mean DFS period of the patients with high and low HIF-3 $\alpha$ expression levels in their tumor tissues were $25.9 \pm 2.6$ and $29.9 \pm 3.3$ months $(P=0.344$, Fig. 2$)$, respectively.

Association between HIF-3 $\alpha$ expression and the expression of $H I F-1 \alpha$ and HIF-2 $\alpha$. A few studies have reported an association between HIF-3 $\alpha$ expression and the expression of HIF-1 $\alpha$ and HIF-2 $\alpha$ (13-15); however, the results are inconsistent or even conflicting. Therefore, we investigated their relationship both in vivo and in vitro. In HCC tissues, Spearman correlation analysis revealed that the expression of HIF-3 $\alpha$ was significantly correlated with the expression of HIF- $2 \alpha\left(r_{\mathrm{s}}=0.198\right.$, $\mathrm{P}=0.030)$, but not with HIF-1 $\alpha$ expression $\left(\mathrm{r}_{\mathrm{s}}=0.045, \mathrm{P}=0.855\right)$ (data not shown). In addition, PLC/PRF/5 and Hep3B cells transfected with either HIF-1 $\alpha$ or HIF- $2 \alpha$ plasmids expressed a higher level of HIF-3 $\alpha$ compared with the pcDNA2.1 control cells. The elevation of HIF-3 $\alpha$ was higher in the HIF- $2 \alpha$ overexpressing cells compared with the HIF-1 $\alpha$ overexpressing 
cells, indicating that HIF- $3 \alpha$ may be a target gene of HIF-1 $\alpha$ and HIF- $2 \alpha$ in PLC/PRF/5 and Hep3B cells, but HIF-3 $\alpha$ is regulated more effectively by HIF-2 $\alpha$ (Fig. 3).

\section{Discussion}

In general, hypoxia is the most important factor involved in the regulation of the expression of HIF- $\alpha$ members. It has been reported that the mRNA and protein levels of HIF- $\alpha$ members are increased in hypoxic environments, and are often overexpressed in hypoxic solid tumors (25). Unlike the observation of consistent increase of HIF- $2 \alpha$ in the majority of tumors, our previous data have shown that the expression patterns of HIF-1 $\alpha$ and HIF-2 $\alpha$ are opposite in HCC and paired peritumoral tissues (18). The level of HIF-1 $\alpha$ in HCC tissues is significantly higher compared with that in peritumoral tissues, whereas the level of HIF- $2 \alpha$ is markedly lower in tumor tissues compared with peritumoral tissues (18). Notably, we did not identify any obvious differences in HIF-3 $\alpha$ expression between $\mathrm{HCC}$ and peritumoral tissues in this study. The expression of HIF-3 $\alpha$ protein was increased in $\sim 50 \%$ of the HCC specimens compared with peritumoral tissues, but was decreased or unaltered in the other $\sim 50 \%$. This discrepancy may be attributed to different sensitivities of HIF-1 $\alpha$, HIF- $2 \alpha$ and HIF-3 $\alpha$ in response to hypoxia. Furthermore, although all HIF- $\alpha$ members are predominantly regulated by oxygen pressure, they are additionally regulated by other factors in the tumor microenvironment. These factors include glucose metabolism and mutations in proto-oncogenes and tumor suppressor genes (26-29). These factors are likely to exert different effects on the expression of HIF- $\alpha$ factors, leading to the upregulation of HIF-1 $\alpha$, the downregulation of HIF-2 $\alpha$ and the inconsistent expression of HIF-3 $\alpha$ in HCC tissues. Therefore, the regulation of HIF- $\alpha$ expression is complicated, and further investigations are required to determine the underling mechanisms that control HIF-3a expression in HCC tissues.

The varying expression patterns of HIF- $\alpha$ factors in HCC tissues indicate that they may serve different functions in response to hypoxia. The transactivation activity of HIF-3 $\alpha$ is different from those of HIF-1 $\alpha$ and HIF-2 $\alpha$ (30). Previous studies have suggested that HIF-3 $\alpha$ may suppress HIF-1 $\alpha$ and HIF- $2 \alpha$ mediated gene expression when the expression of ARNT is limited $(13,31,32)$. Hara et al (12) transfected expression vectors containing HIF- $1 \alpha$, HIF- $2 \alpha$ or HIF- $3 \alpha$ genes into COS-7 cells and found that HIF- $1 \alpha$ and HIF- $2 \alpha$ upregulated the transcription of HRE-driven genes, whereas HIF-3 $\alpha$ inhibited their expression. Recent research has indicated that HIF-3 $\alpha$ is an oxygen-dependent transcription activator, and serves a crucial function in the transcriptional response to hypoxia by binding to target gene promoters, including LC3C, REDD1 and SQRDL, thus stimulating their expression (33). Therefore, further studies are required to investigate the role of HIF-3 $\alpha$ in response to hypoxia.

To reveal the role of HIF-3 $\alpha$ in the development of HCC, we divided the human samples into two groups based on the score of HIF-3 $\alpha$ expression. However, no significant correlation was identified between HIF- $3 \alpha$ expression and the clinicopathological characteristics of HCC samples. Furthermore, no significant correlation was detected between the expression of HIF-3 $\alpha$ in HCC tissues and the OS or DFS of HCC patients. No statistically significant correlation was detected between HIF-3 $\alpha$ expression and the prognosis of HCC patients. However, larger population-based studies are required to confirm the inconsistent expression patterns of HIF-3 $\alpha$ in HCC and to identify the underlying causes.

Previous studies have reported associations among the expression levels of HIF-1 $\alpha$, HIF- $2 \alpha$, and HIF- $3 \alpha$; however, their results are inconsistent or conflicting (13-15,34). Tanaka et al (13) have found that the siRNA-mediated knockdown of HIF-1 $\alpha$ in human renal cell carcinoma notably reduced the 2,2-dipyridyl-induced expression of HIF-3 $\alpha$ protein. In addition, an IHC study revealed an overlapping region with positive HIF-1 $\alpha$ and HIF-3 $\alpha$ expression within the cells (13). These results indicate that HIF-3 $\alpha$ is a target gene of HIF-1 $\alpha$. However, the expression of a stabilized form of HIF- $1 \alpha$ did not alter HIF-3 $\alpha$ mRNA levels in either zebrafish embryos (34) or 3T3-L1 cells (15). Hatanaka et al (15) have observed that HIF- $2 \alpha$ specifically binds to the sequence between -251 and -228 bp upstream of the transcription start site of mouse HIF- $3 \alpha$, which is essential in the response to HIF- $2 \alpha$ stimulation. In human umbilical venous endothelial cells, HIF-3 $\alpha$ expression is promoted by HIF-1 and HIF-2 (14). All these inconsistent results regarding the HIF- $1 \alpha$ - and HIF- $\alpha \alpha$-mediated regulation of HIF-3 $\alpha$ induction may be due to the different cell types used in the experiments. In HCC cell lines, HIF- $1 \alpha$ and HIF-2 $\alpha$ increased the expression of HIF-3 $\alpha$ in PLC/PRF/5 and Hep3B cells. The correlation between HIF- $2 \alpha$ and HIF-3 $\alpha$ expression is more marked, indicating that HIF-3 $\alpha$ may be a target gene of HIF-2 $\alpha$ in both PLC/PRF/5 and Hep3B cells.

In conclusion, despite the structural similarities between HIF-1 $\alpha$, HIF- $2 \alpha$ and HIF-3 $\alpha$, their expression patterns notably differ, indicating that they may play different roles in the development of HCC. The expression of HIF- $3 \alpha$ protein was not associated with histopathological features, OS or DFS in HCC patients. However, HIF-3 $\alpha$ is a potential target gene of HIF- $2 \alpha$ in PLC/PRF/ 5 cells. Further studies are required to confirm the direct regulation of HIF-3 $\alpha$ by HIF- $2 \alpha$.

\section{Acknowledgements}

This study was supported by the National Natural Science Foundation of China (grant no. 81160311).

\section{References}

1. Mucaj V, Shay JE and Simon MC: Effects of hypoxia and HIFs on cancer metabolism. Int J Hematol 95: 464-470, 2012.

2. Cao S, Yang S, Wu C, Wang Y, Jiang J and Lu Z: Protein expression of hypoxia-inducible factor-1 alpha and hepatocellular carcinoma: A systematic review with meta-analysis. Clin Res Hepatol Gastroenterol 38: 598-603, 2014.

3. Aravalli RN, Cressman EN and Steer CJ: Cellular and molecular mechanisms of hepatocellular carcinoma: An update. Arch Toxicol 87: 227-247, 2013.

4. Semenza GL: Oxygen sensing, hypoxia-inducible factors and disease pathophysiology. Ann Rev Pathol 9: 47-71, 2014.

5. Yang SL, Wu C, Xiong ZF and Fang X: Progress on hypoxia-inducible factor-3: Its structure, gene regulation and biological function (Review). Mol Med Rep 12: 2411-2416, 2015.

6. Haase VH: The VHL tumor suppressor: Master regulator of HIF. Curr Pharm Des 15: 3895-3903, 2009.

7. Majmundar AJ, Wong WJ and Simon MC: Hypoxia-inducible factors and the response to hypoxic stress. Mol Cell 40: 294-309, 2010 . 
8. Semenza GL: Hypoxia-inducible factors: Mediators of cancer progression and targets for cancer therapy. Trends in pharmacological sciences 33: 207-214, 2012.

9. Yang Y, Sun M, Wang L and Jiao B: HIFs, angiogenesis and cancer. J Cell Biochem 114: 967-974, 2013.

10. Gu YZ, Moran SM, Hogenesch JB, Wartman L and Bradfield CA Molecular characterization and chromosomal localization of a third alpha-class hypoxia inducible factor subunit, HIF3alpha. Gene Expr 7: 205-213, 1998.

11. Tian H, McKnight SL and Russell DW: Endothelial PAS domain protein 1 (EPAS1), a transcription factor selectively expressed in endothelial cells. Genes Dev 11: 72-82, 1997.

12. Hara S, Hamada J,Kobayashi C, Kondo Y and Imura N: Expression and characterization of hypoxia-inducible factor (HIF)-3alpha in human kidney: Suppression of HIF-mediated gene expression by HIF-3alpha. Biochem Biophys Res Commun 287: 808-813, 2001

13. Tanaka T, Wiesener M, Bernhardt W, Eckardt KU and Warnecke C: The human HIF (hypoxia-inducible factor)-3alpha gene is a HIF-1 target gene and may modulate hypoxic gene induction. Biochem J 424: 143-151, 2009.

14. Augstein A, Poitz DM, Braun-Dullaeus RC, Strasser RH and Schmeisser A: Cell-specific and hypoxia-dependent regulation of human HIF-3 $\alpha$ : Inhibition of the expression of HIF target genes in vascular cells. Cell Mol Life Sci 68: 2627-2642, 2011.

15. Hatanaka M, Shimba S, Sakaue M, Kondo Y, Kagechika H, Kokame K, Miyata T and Hara S: Hypoxia-inducible factor-3alpha functions as an accelerator of 3T3-L1 adipose differentiation. Biol Pharm Bull 32: 1166-1172, 2009.

16. Fang X, Dong W, Thornton C, Scheffler B and Willett KL: Benzo(a)pyrene induced glycine N-methyltransferase messenger RNA expression in fundulus heteroclitus embryos. Mar Environ Res 69 (Suppl): S74-S76, 2010.

17. Fang X, Thornton C, Scheffler BE and Willett KL: Benzo[a] pyrene decreases global and gene specific DNA methylation during zebrafish development. Environ Toxicol Pharmacol 36 40-50, 2013

18. Yang SL, Liu LP, Jiang JX, Xiong ZF, He QJ and Wu C: The correlation of expression levels of HIF-1 $\alpha$ and HIF-2 $\alpha$ in hepatocellular carcinoma with capsular invasion, portal vein tumor thrombi and patients' clinical outcome. Jpn J Clin Oncol 44 159-167, 2014

19. Livak KJ and Schmittgen TD: Analysis of relative gene expression data using real-time quantitative PCR and the 2(-Delta Delta C(T)) Method. Methods 25: 402-408, 2001

20. Dai CX, Gao Q, Qiu SJ, Ju MJ, Cai MY, Xu YF, Zhou J, Zhang BH and Fan J: Hypoxia-inducible factor-1 alpha, in association with inflammation, angiogenesis and MYC, is a critical prognostic factor in patients with HCC after surgery. BMC Cancer 9: 418, 2009.

21. Xiang ZL, Zeng ZC, Fan J, Tang ZY, He J, Zeng HY and Chang JY: The expression of HIF-1 $\alpha$ in primary hepatocellular carcinoma and its correlation with radiotherapy response and clinical outcome. Mol Biol Rep 39: 2021-2029, 2012.
22. Xiang ZL, Zeng ZC, Fan J, Tang ZY, Zeng HY and Gao DM: Gene expression profiling of fixed tissues identified hypoxia-inducible factor-1 $\alpha$, VEGF and matrix metalloproteinase-2 as biomarkers of lymph node metastasis in hepatocellular carcinoma. Clin Cancer Res 17: 5463-5472, 2011.

23. Xie H, Song J, Liu K, Ji H, Shen H, Hu S, Yang G, Du Y, Zou X, Jin $\mathrm{H}$, et al: The expression of hypoxia-inducible factor-1alpha in hepatitis B virus-related hepatocellular carcinoma: Correlation with patients' prognosis and hepatitis B virus X protein. Dig Dis Sci 53: 3225-3233, 2008.

24. Yang SL, Yu C, Jiang JX, Liu LP, Fang X and Wu C: Hepatitis B virus $X$ protein disrupts the balance of the expression of circadian rhythm genes in hepatocellular carcinoma. Oncol Lett 8: 2715-2720, 2014

25. Semenza GL: HIF-1 mediates metabolic responses to intratumoral hypoxia and oncogenic mutations. J Clin Invest 123: 3664-3671, 2013

26. Tsapournioti S, Mylonis I, Hatziefthimiou A, Ioannou MG, Stamatiou R, Koukoulis GK, Simos G, Molyvdas PA and Paraskeva E: TNF $\alpha$ induces expression of HIF- $1 \alpha$ mRNA and protein but inhibits hypoxic stimulation of HIF-1 transcriptional activity in airway smooth muscle cells. J Cell Physiol 228: 1745-1753, 2013

27. Kilic-Eren M, Boylu T and Tabor V: Targeting PI3K/Akt represses hypoxia inducible factor- $1 \alpha$ activation and sensitizes rhabdomyosarcoma and Ewing's sarcoma cells for apoptosis. Cancer Cell Int 13: 36, 2013.

28. Chen C, Cai S, Wang G, Cao X, Yang X, Luo X, Feng Y and $\mathrm{Hu} \mathrm{J}$ : c-Myc enhances colon cancer cell-mediated angiogenesis through the regulation of HIF-1 $\alpha$. Biochem Biophys Res Commun 430: 505-511, 2013

29. Agani F and Jiang BH: Oxygen-independent Regulation of HIF-1: Novel Involvement of PI3K/AKT/mTOR pathway in cancer. Curr Cancer Drug Targets 13: 245-251, 2013.

30. Li QF, Wang XR, Yang YW and Lin H: Hypoxia upregulates hypoxia inducible factor (HIF)-3alpha expression in lung epithelial cells: Characterization and comparison with HIF-1alpha. Cell Res 16: 548-558, 2006.

31. Maynard MA, Evans AJ, Hosomi T, Hara S, Jewett MA and Ohh M: Human HIF-3alpha4 is a dominant-negative regulator of HIF-1 and is down-regulated in renal cell carcinoma. FASEB J 19: 1396-1406, 2005.

32. Maynard MA, Evans AJ, Shi W, Kim WY, Liu FF and Ohh M Dominant-negative HIF-3 alpha 4 suppresses VHL-null renal cell carcinoma progression. Cell Cycle 6: 2810-2816, 2007.

33. Zhang P, Yao Q, Lu L, Li Y, Chen PJ and Duan C: Hypoxia-inducible factor 3 is an oxygen-dependent transcription activator and regulates a distinct transcriptional response to hypoxia. Cell Rep 6: 1110-1121, 2014.

34. Zhang P, Lu L, Yao Q, Li Y, Zhou J, Liu Y and Duan C: Molecular, functional and gene expression analysis of zebrafish hypoxia-inducible factor-3 $\alpha$. Am J Physiol Regul, Integr Comp Physiol 303: R1165-R1174, 2012. 